\title{
THE DEVIL IS IN THE SCALE: \\ REVISITING THE COMMONALITY REQUIREMENT in Charter Class ACtions
}

\author{
IRYNA PONOMARENKO*
}

\begin{abstract}
Even a cursory look at the literature reveals scant agreement among experts on the future of Charter class actions. In no small part, this uncertainty can be attributed to the divergent views among the courts concerning the proper contours of the commonality threshold for aggregate Charter proceedings. While the doctrinal narrative of Thorburn suggests that Charter rights are individual in nature and, thus, are not easily amenable to collective redress, the counter-narrative delivered by Good posits that in order for a Charter class action to pass the commonality hurdle of certification "it does not have to resolve all issues that may exist in terms of establishing liability." Although it is easy to see Thorburn and Good as thesis and antithesis, the subsequent Charter class actions such as Murray can hardly be portrayed as a synthesis. Hence, uncertainty over the commonality standard reigns.
\end{abstract}

Taking these observations as its guiding thread, this article makes a case for revisiting the commonality requirement in Charter class actions and argues that "over-individualization" of Charter rights that has been imputed into the analysis by Thorburn is unjustified on both descriptive and normative levels. Descriptively, such "over-individualization" is misguided because it semantically overpowers the analysis which, if properly conducted, would often reveal either no need for individual fact-finding at all or the possibility to follow the resolution of common issues with individual mini-trials. Normatively, overreliance on individualized inquiries as part of the commonality analysis is misguided because it misconstrues the very nature of the class action regime.

\section{TABLE OF CONTENTS}

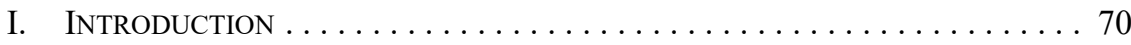

II. THE PROMises AND Perils of CHARTER Class ACtions $\ldots \ldots \ldots \ldots .73$

A. Why CHARTER Class Actions? .................. 73

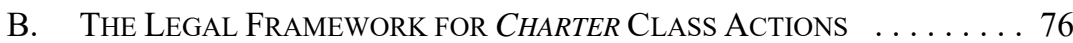

III. THORBURN VERSUS GOOD:

Two Monologues Do Not Make a Dialogue $\ldots \ldots \ldots \ldots \ldots . . .81$

A. THORBURN V. BRITISH COLUMBiA

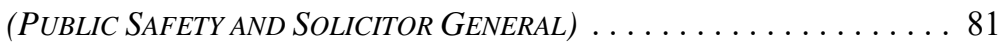

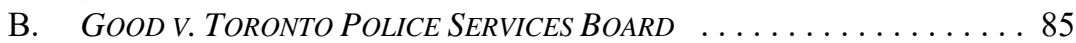

IV. The Form-Substance Dialectics in CHARTER Class Actions . . . . . 87

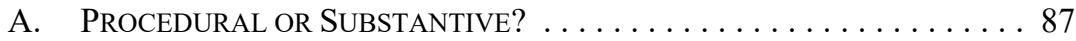

B. GLOSSING OVER INDIVIDUALIZED INQUIRIES in AgGRegate Litigation . . . . . . . . . . . . . . . . . . . . . . 89

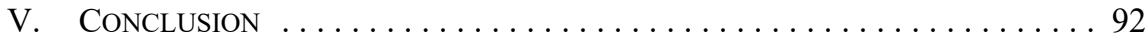

PhD Candidate, Allard School of Law, University of British Columbia. 


\section{INTRODUCTION}

The Canadian Charter of Rights and Freedoms ${ }^{1}$ is now more than thirty years in the making, yet, to borrow from Martin Luther King, many of its potential beneficiaries are still standing outside the "palace of justice" waiting to be let in. ${ }^{2}$ At the heart of this access-tojustice crisis ${ }^{3}$ are largely pragmatic reasons: Charter grievances are prohibitively costly to lodge, are unreasonably time-consuming, and offer so little (if any) financial relief ${ }^{4}$ that it takes a very "economically irrational" applicant to even venture to bring a claim. ${ }^{5}$

At first glance, the idea of a Charter class action-a procedural vehicle that helps disenfranchised claimants to enhance a financial utility of their grievances through a plaintiff-friendly statutory regime - offers hope to those barred from seeking warranted Charter redress. As everyone knows, there is safety in numbers. Notwithstanding the vast appeal of aggregate litigation in the private domain, however, the notion of Charter class actions has proven to be quite divisive, as least on the conceptual side of things. While some constitutional scholars argue that there is a "natural fit" between class actions and constitutional claims, ${ }^{6}$ others submit that constitutional rights — by their very nature resist aggregate treatment. ${ }^{7}$

The courts are equally divided on the issue. In Thorburn v. British Columbia (Public Safety and Solicitor General), the British Columbia Court of Appeal found that a class proceeding implicating section 8 of the Charter could not be certified because "a Charter right is individual in nature" ${ }^{\prime 8}$ and the need to give individual treatment to each rights violation $^{9}$ ran afoul of the commonality requirement under section 4 of the provincial Class Proceedings Act. ${ }^{10}$ Conversely, in Sherry Good v. Toronto (Police Services Board), the Ontario Superior Court of Justice (Divisional Court) held that in order for a section 9 Charter class action to pass the commonality hurdle, "it does not have to resolve all issues that may exist in terms of establishing liability." "In the aftermath of Good, the divide has only persisted. In one of the recent mass Charter cases - Murray v. East Coast Forensic Hospital - the Court certified a class of Charter claimants by operating on the assumption

Part I of the Constitution Act, 1982, being Schedule B to the Canada Act 1982 (UK), 1982, c 11 [Charter].

Martin Luther King Jr., "I Have a Dream" (Speech delivered on the steps at the Lincoln Memorial, Washington, DC, 28 August 1963), online: <avalon.law.yale.edu/20th_century/mlk01.asp>.

See e.g. Chief Justice Beverley McLachlin, "The Challenges We Face" (Remarks delivered to the Empire Club of Canada, Toronto, 8 March 2007), online: <www.cfcj-fcjc.org/sites/default/files/docs/ 2007/mclachlin-empireclub-en.pdf>.

Ranjan Agarwal \& Joseph Marcus, "Where There is No Remedy, There is No Right: Using Charter Damages to Compensate Victims of Racial Profiling" (2015) 34:1 NJCL 75 at 77.

Kent Roach, "Models of Civilian Police Review: The Objectives and Mechanisms of Legal and Political Regulation of the Police" (2014) 61:1 Crim LQ 29 at 67.

Joseph J Arvay \& David W-L Wu, "Class Actions and the Charter" (Paper delivered at the 14th National Symposium on Class Actions, Toronto, 6-7 April 2017) at 1 [emphasis added].

On this phenomenon in American jurisprudence, see e.g. Brandon L Garrett, "Aggregation and Constitutional Rights" (2012) 88:2 Notre Dame L Rev 593.

2013 BCCA 480 at para 41 [Thorburn BCCA], aff'g 2012 BCSC 1585 [Thorburn BCSC].

As the Court stipulated, "only an individual assessment of the relevant circumstances unique to each class member would allow a judge to determine if a cause of action had been established" (ibid). RSBC 1996, c 50.

Sherry Good v Toronto Police Services Board, 2014 ONSC 4583 at para 45 [Good ONSC], aff'd 2016 ONCA 250 [Good ONCA]. 
that Thorburn had been correctly decided, but that the case at hand could be distinguished from Thorburn on the facts and that the reasoning from Good was in order. ${ }^{12}$

It is worth noting that an uncertainty as to what it takes for a constitutional right claim to satisfy the commonality requirement of certification is not sui generis to Canada. A vibrant controversy regarding amenability of constitutional rights to consolidated redress unfolds in the United States in the wake of a high-profile and highly polarizing 5-4 decision in WalMart Stores, Inc. v. Dukes. ${ }^{13}$ In a case focusing on sex discrimination at the workplace, the majority of the American apex court decided to decertify the class due to what they described as the lack of requisite commonality under Federal Rule of Civil Procedure 23(a). The Court held that the emphasis on statistical evidence and corporate culture was insufficient to prove systemic discrimination and could not supersede the need to give individual treatment to each particular human rights grievance. ${ }^{14}$ At first glance, Thorburn and Wal-Mart appear to have at least three things in common: first, both cases stand for the proposition that the need for individualized inquiry into each constitutional breach (such as individual fact-finding) bars the determination of sufficient commonality in mass civil rights cases; second, both cases postulate that "unreasonable policy alone could not provide the foundation for determining each class member's cause of action", ${ }^{15}$ third, as will be evinced in one of the subsequent sections, this article respectfully holds that both cases were wrongly decided.

The issue is not merely of theoretical import. Joseph Arvay and David Wu argue that the lack of a uniform treatment of the "commonality" hurdle of certification is "[o]ne of the biggest barriers" $" 16$ to obtaining certification in Charter class actions. Other commentators concur in this assessment. ${ }^{17}$

Taking these observations as its guiding thread, this article makes a case for revisiting the Thorburn approach to a determination of commonality and argues for judicial caution in over-relying on "individualized fact-finding" and "individualized inquiries" in aggregate Charter proceedings. The reason for such caution is twofold. On the descriptive level, "overindividualization" of constitutional rights is often misguided because it semantically overpowers the analysis which, if properly conducted, would reveal either (1) barely any

2015 NSSC 61 at paras 64-78 [Murray NSSC], aff'd 2017 NSCA 29 [Murray NSCA].

564 US 338 (2011) [Wal-Mart].

Ibid at 19 .

Thorburn BCCA, supra note 8 at para 41. Cf Wal-Mart, ibid at 357: while the majority acknowledged that Wal-Mart's policy of "giving discretion to lower-level supervisors can be the basis of Title VII liability under a disparate-impact theory," the Court nonetheless held that "the recognition that this type of Title VII claim 'can' exist does not lead to the conclusion that every employee in a company using a system of discretion has such a claim in common."

Arvay \& Wu, supra note 6 at 11 .

As Ranjan Agarwal and Joseph Marcus submit, the unanimous decision in Thorburn "casts some doubt on [the] potential for a successful racial profiling class action" (Agarwal \& Marcus, supra note 4 at $n$ 122). See also Regan S Christensen, "No Right Without a Remedy? The Potential Role of Class Actions in Police Accountability and Defending Charter Rights" (2016) 11:2 Can Class Action Rev 201. Likewise, in the wake of the Court of Appeal's decision in Thorburn, Jasminka Kalajdzic noted that if the precedent stays, "any class action pursuing a Charter remedy is unlikely to succeed" (Michael Benedict, "Strip-Search Class Action Refused on Appeal," The Lawyers Weekly 33:30 (6 December 2013) 3, cited in Christensen, ibid at 231, n 108). 
need for individual fact-finding at all (as in Thorburn) $;{ }^{18}$ or (2) the possibility to follow the resolution of common issues with numerous individual mini-trials (as in Wal-Mart). ${ }^{19}$

On the normative level, overreliance on individualized inquiries as part of the "commonality" analysis is misguided because it misconstrues the very nature of the class action regime. What often escapes scholarly attention is that in the furtherance of certain policy goals (such as judicial efficiency, access to justice, and behaviour modification), ${ }^{20}$ the procedural vehicle of a class action is allowed to affect the substantive rights of the parties to the dispute. The latter frequently includes substitution of individual with aggregate factfinding (for example, substituting individualized proof with aggregate proof or using statistical evidence), ${ }^{21}$ substitution of negligence with strict liability, ${ }^{22}$ and so on. Thus, if the policy tail is permitted to wag the legal dog in, say, mass tort litigation, it is not immediately clear why the same idea of substituting individual with aggregate inquiries in the furtherance of certain policy gains cannot be warranted in Charter class actions, especially having regard to a broader palette of policy gains in the constitutional arena. Furthermore, the class proceeding statutes explicitly vest the courts with large discretionary powers to navigate the new frontiers of aggregate litigation as well as to overcome the hindrances presented by the individual issues inherent in any collective dispute. ${ }^{23}$

It appears, thus, that there are two sides to what has been called "[ $\mathrm{t}]$ he Uncertain Legacy of Thorburn and Good." 24 On the one (negative) hand, these cases have created something akin to "jurisprudential parting of the waters" in the context of Charter class actions, with courts and potential claimants alike left confounded as to what it now takes for a Charter action to satisfy the commonality requirement of certification. ${ }^{25}$ The vague language of Thorburn (at some point, the Court went as far as to state that the problem with the "proposed common issues" was "the lack of commonality") ${ }^{26}$ only compounds matters. Yet on the other (positive) hand, the Thorburn versus Good dichotomy offers an unparalleled opportunity for the courts to go back to the drawing board and shape a revisited - on both descriptive and normative levels - commonality standard in Charter class actions. To offer a starting point for such revision, as well as to draw out the ways in which scholars and

18 See Part III.A, below.

19 As many commentators observe, in some post-Wal-Mart cases American courts did just that. See e.g. McReynolds v Merrill Lynch \& Co, 694 F (3d) 873 (7th Cir 2012).

20 Western Canadian Shopping Centres Inc v Dutton, 2001 SCC 46 at paras 27-29 [Dutton]. See also Mathew Good, "Access to Justice, Judicial Economy, and Behaviour Modification: Exploring the Goals of Canadian Class Actions" (2009) 47:1 Alta L Rev 185.

21 This is a common practice in American class action litigation. For a Canadian perspective, see e.g. Clements $v$ Clements, 2012 SCC 32 at para 44, where Chief Justice McLachlin leaves the door open for the use of statistical evidence in mass toxic tort litigation. Likewise, statistical evidence is increasingly employed in discrimination law, both in Canada and in the United States (Jamie Cassels \& Craig Jones, The Law of Large-Scale Claims: Product Liability, Mass Torts, and Complex Litigation in Canada (Toronto: Irwin Law, 2005) at 250).

22 While there is no doctrine of strict liability for product liability in Canada, substitution of negligence for strict liability for the purposes of class action adjudication is a common practice in the United States. Furthermore, as Jamie Cassels and Craig Jones posit, a close analysis suggests that in practice Canadian courts hold manufacturers to the levels of accountability that actually "come close to strict liability" (Cassels \& Jones, ibid at 96).

23 Heather McCleod-Kilmurray, "Hollick and Environmental Class Actions: Putting the Substance into Class Action Procedure" (2003) 34:2 Ottawa L Rev 263 at 269.

Christensen, supra note 17 at 241.

Wilson v Atomic Energy of Canada Ltd, 2016 SCC 29 at para 61.

Thorburn BCSC, supra note 8 at para 94. Cf Thorburn BCCA, supra note 8 at para 42 (the Court of Appeal held " $[\mathrm{t}] \mathrm{h}$ e resolution of these 'common issues' in practical terms resolves no 'common' element of each member's cause of action"). 
judges can begin grappling with the issue of commonality from a theoretically informed standpoint, is the modest aspiration of this essay.

\section{The Promises and Perils of Charter Class Actions}

\section{A. Why Charter Class Actions?}

\section{OVERVIEW}

In civil litigation, the procedural vehicle of a class action is widely acclaimed for its Midas touch. Indeed, claim aggregation can easily transform low-value, high-maintenance grievances that cannot otherwise be economically pursued into substantial gains accruing to a great number of individuals. Albeit not without a caveat, these advantages of a class action, which are achieved through an "economy of scale" approaching the one that large institutional defendants routinely enjoy, ${ }^{27}$ can be extrapolated onto Charter litigation.

Overall, the benefits of procedural consolidation in the Charter context can be divided into two groups: those naturally stemming from the aggregation of otherwise excessively timeand resource-intensive claims and those afforded to the claimants by the statutorily created class action regimes.

\section{GENERAL AdVANTAGES}

In Hollick v. Toronto (City) ${ }^{28}$ and Western Canadian Shopping Centres Inc. v. Dutton, ${ }^{29}$ the Supreme Court of Canada has articulated three principal — naturally transpiring advantages and aspirations of consolidated litigation: access to justice, judicial economy, and behaviour modification. ${ }^{30}$ It is of important note that these policy objectives are complementary to the policy objectives of Charter damages. ${ }^{31}$ As Craig Jones submits, of the three stated goals of class actions, behaviour modification contributes most significantly to the minimization of externalities associated with otherwise unactionable mass wrongs. ${ }^{32}$ This sentiment is echoed by Joseph Arvay and David Wu, who assert that Charter class actions are a "useful and increasingly popular means" to keep law enforcement and other governmental bodies accountable. ${ }^{33}$ In the words of the Supreme Court in Dutton:

Without class actions, those who cause widespread but individually minimal harm might not take into account the full costs of their conduct, because for any one plaintiff the expense of bringing suit would far exceed the likely recovery. Cost-sharing decreases the expense of pursuing legal recourse and accordingly deters potential defendants who might otherwise assume that minor wrongs would not result in litigation. ${ }^{34}$

Craig Jones, Theory of Class Actions (Toronto: Irwin Law, 2003) at 4.

2001 SCC 68 at paras 15, 27 [Hollick].

Dutton, supra note 20 at paras 27-29.

For some criticism, see Brian Smith, "Class Reunion: Revisiting Class Action Justification After Twenty Years" (2011) 7:1 Can Class Action Rev 33.

Vancouver (City) v Ward, 2010 SCC 27 [Ward].

Jones, supra note 27 at 4.

Arvay \& Wu, supra note 6 at 1 .

Dutton, supra note 20 at para 29. 
As noted above, implicit in this statement is the idea of achieving efficiency through what is known as "economies of scale" 35 — the proposition that individual investment in litigation decreases as the number of plaintiffs increases. Normally, as Regan Christensen observes, when one contrasts the limited economic means of those who are most often victims of government misconduct with the comparatively unlimited resources of governments "who are willing to appeal pre-trial motions up to the highest levels of court, it is not difficult to see why even those with meritorious cases might be dissuaded from using civil lawsuits to protest ... violations of their rights. ${ }^{, 36}$ However, the procedural benefits that the class action regime brings to bear on otherwise hopeless piecemeal litigation can mute the "unfair" advantages enjoyed by large institutional defendants, such as governments. Thus, as asserted in Dutton, "by allowing fixed litigation costs to be divided over a large number of plaintiffs, class actions improve access to justice by making economical the prosecution of claims that would otherwise be too costly to prosecute individually." 37

The access-to-justice agenda of Charter class actions is closely linked to class actions' prospective ability to bring about systemic constitutional changes. As one American commentator has aptly put it, "[c]ivil rights and class actions have an historic partnership." 38 It is worth remembering that the landmark desegregation case of Brown v. Board of Education of Topeka was a class action lawsuit. ${ }^{39}$ Today, a host of Canadian commentators make a similar case for engaging and channeling a transformative power of procedural aggregation in order to remedy systemic problems of public interest. Joseph Arvay and David $\mathrm{Wu}$ say that they "see great potential" for the use of Charter class actions in "combating systemic discrimination that is often well-hidden or firmly institutionalized." 40 In a similar vein, Ranjan Agarwal and Joseph Marcus suggest that seeking Charter damages through a procedural vehicle of a class action may be the only financially viable route for victims of racial profiling. ${ }^{41}$

Complementary to these benefits is another one: Charter class actions can provide some level of much-needed anonymity for the victims of systemic, race- or gender-based, abuse perpetrated by the officers of the state. ${ }^{42}$ Conversely, claim aggregation has an advantage of providing better access to information to those wronged by the state. ${ }^{43}$ As one American judge has pertinently observed in the context of a class action challenging strip searches of detainees:

Absent class certification and its attendant class-wide notice procedures, most of these individuals - who potentially number in the thousands - likely never will know that defendants violated their clearly established constitutional rights, and thus never will be able to vindicate those rights. ${ }^{44}$

Garrett, supra note 7 at 613 .

Christensen, supra note 17 at 209.

Dutton, supra note 20 at para 28.

Garrett, supra note 7 at 606, citing Jack Greenberg, "Civil Rights Class Actions: Procedural Means of Obtaining Substance” (1997) 39:2 Ariz L Rev 575 at 577.

347 US 483 (1954).

Arvay \& Wu, supra note 6 at 1 .

Agarwal \& Marcus, supra note 4 at 97.

Ibid.

Garrett, supra note 7 at 614.

Augustin v Jablonsky (In re Nassau County Strip Search Cases), 461 F (3d) 219 at 229 (2d Cir 2006). 
Further advantages vest in Charter claimants who opt for aggregation. Class members are often uniquely positioned to avail themselves of the benefits of aggregate evidence when challenging institution-wide practices - something individual claimants have neither money nor capacity to pursue. Not only, as a practical matter, may a counsel for the class be better situated to spread the costs of obtaining such evidence, ${ }^{45}$ but a consolidated action may greatly benefit from "pooling of information gathered from class members." 46 Indeed, an argument can be made that "[c]lass actions are uniquely suitable for litigating discrimination claims under the pattern and practice framework."

Likewise, class actions provide improved access to legal representation as "better lawyers may be attracted to a class case involving larger issues and greater financial rewards." ${ }^{48}$ Another curious collateral benefit of bringing a Charter lawsuit as part of an aggregate claim is that the Court may raise larger issues as part of construing the Constitution (as opposed to applying the rights in an individualized manner), ${ }^{49}$ not to mention a very commonsensical proposition that mass litigation creates a societal and media pressure on the government. Indeed, on the Charter battlefield, one man is frequently no warrior, while 100 or even 1,000 can raise the social awareness and bring the media pressure to bear on the resolution of systemic constitutional wrongs.

\section{STATUTORILY CREATED AdVANTAGES}

The second group of advantages conferred upon Charter claimants by the class action regime stems directly from the statutory schemes drafted in each Canadian province. This means that, by virtue of the legislative intervention, the Charter claimants may now enjoy special advantages that they otherwise would not have had they decided to sue the government in their individual capacity. While there were attempts by the courts to implement some common law class action benefits (in 2000, the Supreme Court of Canada even held that class proceedings could be conducted in the absence of class legislation), ${ }^{50}$ the real advantages afforded to the claimants have really only crystallized as part of the class proceeding statutes. These statutes are very similar to each other and are all modeled on the Ontario legislation.

As Kent Roach observes, all statutory benefits of the class action regime can be divided into three groups: (1) insulation from the threat of adverse cost awards, either by the operation of class proceedings statutes, as in British Columbia, or through mechanisms such

AT\&T Mobility LLC v Concepcion, 563 US 333 (2011) (Amicus brief filed by the NAACP Legal Defense \& Educational Fund, Inc. in Support of Respondents) at 19, online: <www.americanbar.org/ content/dam/aba/publishing/preview/publiced_preview_briefs_pdfs_09_10_09_893_RespondentAm CuNAACPLDEF.pdf>.

$46 \quad$ Garrett, supra note 7 at 614.

$47 \quad$ Employees Committed for Justice v Eastman Kodak Co, 407 F Supp (2d) 423 at 428 (WDNY 2005).

48 Garrett, supra note 7 at 614. Note, however, that in the aftermath of Canada (Attorney General) $v$ Hislop, 2007 SCC 10 [Hislop], class counsel may now be deterred from taking on Charter class actions involving government entitlements (as opposed to, for instance, cases involving damage awards) because the finding in Hislop has hampered the ability of class counsel to collect their contingency fees. For more on this, see Jasminka Kalajdzic, Class Actions in Canada: The Promise and Reality of Access to Justice (Vancouver: UBC Press, 2018) at 33-36. As the author reports, some class counsel view the finding in Hislop as "the death knell" of constitutional class actions where benefits or entitlements might be at issue (ibid at 34).

49 Garrett, ibid at 641 .

50 Dutton, supra note 20. 
as the Ontario Law Foundation's Class Proceedings Fund; (2) the ability to determine a defendant's liability to a class on an aggregate basis and to rely upon statistical evidence, something that is not normally available to individual claimants; and (3) the broad statutory discretion "to modify the rules of civil procedure to accommodate the unique needs of each class action."

Admittedly, copious advantages conferred onto Charter claimants by the class action regime have a fair share of their "ifs" and "buts." First and foremost, some commentators claim that the transformative potential of class actions as well as their ability to foster muchneeded access to justice have been overstated. Jasminka Kalajdzic in her graduate thesis argues that, based on a survey of class actions certified in Ontario and interviews with plaintiffs' counsel, "class actions have enhanced access to justice less than was expected."52 Another difficulty with pursuing Charter — as opposed to civil — class actions is that the defendant can never fully internalize the inflicted harm, at least in the strictest sense, because whatever monetary recovery the plaintiff would obtain would always be taken from the taxpayers' pockets, possibly even the very people who end up being judgment creditors in a given case. Among other difficulties with pursuing Charter class actions, as Joseph Arvay and David $\mathrm{Wu}$ actively emphasize, is the scarcity of the remedial menu available to the claimants, especially having regard to the Court's suggestions that "Charter damages under s. 24(1) generally cannot be coupled with declaratory relief under s. 52." 53

\section{B. The Legal Framework for Charter Class ACTIONS}

\section{CERTIFICATION OVERVIEW}

When a class action is commenced, the legislation mandates that a pre-trial motion must be brought seeking certification of the action "as a class action." certification is an alpha and omega of a class action proceeding because, as has been noted by commentators as recently as 2017, "[r]elatively few Canadian class action cases ultimately go through to trial." ${ }^{55}$ Indeed, "[t]he general trend in Canadian class proceedings over the past several decades has been that cases either fail at certification or are settled following a successful certification." "T6 Thus, once passed through the hurdle of certification, most cases become "too big to fail." Statistical evidence bears out this observation. ${ }^{57}$

$51 \quad$ Christensen, supra note 17 at 215.

52 Kent Roach \& Lorne Sossin, “Access to Justice and Beyond" (2010) 60:2 UTLJ 373 at 378, n 19, citing Jasminka Kalajdzic, "Access to Justice for the Masses? A Critical Analysis of Class Actions in Ontario" (LLM Thesis, University of Toronto, 2009). Kalajdzic further confirmed this finding in her monograph published in 2018: Kalajdzic, supra note 48.

$53 \quad$ Arvay \& Wu, supra note 6 at 2.

54 WA Bogart, Jasminka Kalajdzic \& Ian Matthews, "Class Actions in Canada: A National Procedure in a Multi-Jurisdictional Society?" (Paper delivered at The Globalization of Class Actions Conference, Oxford University, December 2007) at 6 [emphasis added], online: < globalclassactions.stanford.edu/ sites/default/files/documents/Canada_National_Report.pdf $>$. If certification is refused, the action may be brought by the various proposed class members as individual actions.

55 Mathew P Good, "Class Action Case Study: From Certification to Trial in Jer v Samji” (2017) 12:2 Can Class Action Rev 261 at 261.

$56 \quad$ Ibid at 263.

57 Ibid. See also Ward K Branch, Class Actions in Canada, vol 2 (Toronto: Thomson Reuters, 2016) (loose-leaf updated June 2016), ch 22. 
With the exception of Quebec, ${ }^{58}$ the test for certification is almost identical in each of Canada's provinces. ${ }^{59}$ In British Columbia, the requirements for class certification are set out in section 4 of the Class Proceedings Act. A combined total of five criteria ought to congregate for a non-discretionary obligation to arise on the part of the court to certify a proceeding as a class proceeding:

a. Cause of action - "the pleadings disclose a cause of action";

b. Identifiability - "there is an identifiable class of 2 or more persons";

c. Commonality — "the claims of the class members raise common issues...";

d. Preferability — "a class proceeding would be the preferable procedure for the fair and efficient resolution of the common issues";

e. Adequate representation — "there is a representative plaintiff who ... would fairly and adequately represent the interests of the class." 60

The courts have long acknowledged that the certification stage does not place an onerous standard of proof on the claimant and, as established in Hollick, all the plaintiff must show is that there is some "basis in fact" for each of the certification requirements, other than the requirement that the pleadings disclose a cause of action. ${ }^{61}$

Implicit in this requirement is an idea that, pursuant to section 5(7) of the Class Proceedings Act, an order certifying a proceeding as a class proceeding is not a determination of the merits of the proceeding.

While the standard of proof is not "onerous," it is not non-existent. As the courts repeated once and again, "there must be a substantial common ingredient in the proposed class action in order for a court to be satisfied that the ends of fairness and efficiency are best served by class certification." 62

\section{FLEXIBLE AND LIBERAL APPROACH}

Chief Justice McLachlin, writing for the Supreme Court of Canada in Hollick, advised courts to adopt a broader understanding of class proceedings legislation to make sure that the benefits foreseen by the drafters were given full effect. ${ }^{63}$ In Rumley, she interpreted the Class Proceedings Act as providing British Columbia courts with "ample flexibility to deal with limited differentiation" amongst class members. ${ }^{64}$ Another good example of the Supreme

See Vivendi Canada Inc v Dell'Aniello, 2014 SCC 1 at para 57.

Christensen, supra note 17 at 221.

Class Proceedings Act, supra note 10, s 4. The imperative language of the word "must" used in section 4 signals the non-discretionary nature of this obligation.

${ }_{61}$ Hollick, supra note 28 at para 25, cited with approval in Ernewein v General Motors of Canada Ltd, 2005 BCCA 540 at para 25.

Thorburn BCSC, supra note 8 at para 12.

Hollick, supra note 28.

Rumley v British Columbia, 2001 SCC 69 at para 32 [Rumley]. See also MacKinnon v National Money Mart Company, 2006 BCCA 148 at para 16. 
Court exercising such flexibility is the judgment in Dutton, whereby discretion was exercised by judges to strike a balance between efficiency and fairness considerations, which led the Supreme Court to find that the basic conditions for a class action were met. ${ }^{65}$

\section{COMMONALITY}

Courts have repeatedly noted that the resolution of common issues is "the heart of a class proceeding." ${ }^{96}$ Unfortunately, however, as stated in the landmark decision in Dutton, "[c]ommonality tests have been a source of confusion in the courts." ${ }^{67}$ At its core, according to the Supreme Court, certification of a common issue should turn on whether "the class members' claims ... share a substantial common ingredient to justify a class action." ${ }^{\prime 68}$

What does "substantial common ingredient" mean? It is worth starting with the observation of what it does not mean. It is clear that it does not mean that common issues should predominate over issues affecting only individual members because section 4 of the British Columbia Class Proceedings Act explicitly excludes predominance from the ambit of the commonality inquiry. Arguably, it has been done to counter the American framework, which heavily relies on predominance considerations. Indeed, US Rule 23's "opt-out" scheme requires that the "questions of law or fact common to the members of the class predominate" over individual inquiries. ${ }^{69}$ Conversely, as explained by Justice Smith in Endean v. Canadian Red Cross Society:

The question of whether individual issues predominate over common issues, which so permeates the American law on this subject, is expressly excluded as a relevant consideration by s. 4(1)(c) of the [British Columbia Class Proceedings Act]. Further, a common issue need not be dispositive of the litigation. A common issue is sufficient if it is an issue of fact or law common to all claims, and that its resolution in favour of the plaintiffs will advance the interests of the class, leaving individual issues to be litigated later in separate trials, if necessary. ${ }^{70}$

Now, one may argue that the predominance requirement sneaks in through the "preferability" prong of certification, ${ }^{71}$ which in section $4(2)$ (a) provides that in determining whether a class proceeding would be the preferable procedure, the court must consider all relevant matters, including whether questions of fact or law common to the members of the class predominate over any questions affecting only individual members. However, given that there are five "relevant matters" to be taken into an equation as part of the section 4(2)(a) analysis, ${ }^{72}$ it appears that predominance is not prima facie dispositive of the matter. And

\footnotetext{
Dutton, supra note 20.

See e.g. Campbell v Flexwatt Corp (1997), [1998] 6 WWR 275 at para 52 (BCCA) [Campbell]. See also Thorburn BCCA, supra note 8 at para 35.

Dutton, supra note 20 at para 39.

Ibid [emphasis added].

Jones, supra note 27 at 121.

(1997), 148 DLR (4th) 158 at 167 (BCSC).

As the Supreme Court held in Rumley, supra note 64 at para 32: "predominance will be a factor in the preferability requirement."

Other issues, listed in section 4(2) of the Class Proceedings Act, supra note 10, include:

(b) whether a significant number of the members of the class have a valid interest in individually controlling the prosecution of separate actions;

(c) whether the class proceeding would involve claims that are or have been the subject of any other proceedings;
} 
while the interplay between the commonality and preferability of a class action is substantial, ${ }^{73}$ the interpretation rule against surplusage ${ }^{74}$ mitigates against considering predominance as a dispositive factor at the certification. Thus, it is reasonable to conclude that the "substantial common ingredient" is a lower threshold than "predominance of common over individual issues."

At the other end of the spectrum, common issues do not mean any issues, but substantial ones - the ones that would advance the claim "to an appreciable extent." 75 As Chief Justice McLachlin emphasized in Rumley, the ends of fairness and efficiency are not served by certifying issues that are common only in the most general of terms. ${ }^{76}$ Likewise, if the common issue is conceived in the "most general of terms" and a class action is at risk to break down into substantial individual trials, it will not pass the preferability hurdle either because, as stated in Tiemstra, it will not "promote judicial economy or improve access to justice." 77 Thus, a class would only be certified if the common issue raises "a triable factual or legal issue, the determination of which will move the litigation forward."

\section{As underscored in Thorburn:}

Certification of a common issue will not move the litigation forward if: (i) it is dependent on individual findings of fact that must be made for each class member ...; (ii) it is framed in overly broad terms ...; or (iii) it is not capable of benefiting all members of the class if successfully prosecuted.... In these instances the practical effect of certifying a class action would break down into numerous individual proceedings and therefore would not serve the ends of fairness or efficiency. ${ }^{79}$

Importantly, as Jones aptly observes, the common issue per se does not have to be "at issue" between the parties: "[I]n other words, the defendant cannot escape certification by admitting liability and therefore denying that its culpability is a common issue." 80

In Singer v. Schering-Plough Canada Inc., Justice Strathy provided a non-exhaustive list of general propositions in respect of common issues:

A: The underlying foundation of a common issue is whether its resolution will avoid duplication of factfinding or legal analysis....

$B$ : The common issue criterion is not a high legal hurdle, and an issue can be a common issue even if it makes up a very limited aspect of the liability question and even though many individual issues remain to be decided after its resolution....

(d) whether other means of resolving the claims are less practical or less efficient;

(e) whether the administration of the class proceeding would create greater difficulties than those likely to be experienced if relief were sought by other means.

Jones, supra note 27 at 123.

Where one reading of a statute would make one or more parts of the statute redundant and another reading would avoid the redundancy, the other reading is preferred.

Jones, supra note 27 at 122 .

Rumley, supra note 64 at para 29.

Tiemstra v Insurance Corp of British Columbia (1997), 149 DLR (4th) 419 (BCCA) at para 17.

Thorburn BCCA, supra note 8 at para 38.

Ibid at para 39 [citations omitted].

Jones, supra note 27 at 122. See also Dalhuison v Maxim's Bakery, 2002 BCSC 528. 
$C$ : There must be a basis in the evidence before the court to establish the existence of common issues....

$D$ : In considering whether there are common issues, the court must have in mind the proposed identifiable class. There must be a rational relationship between the class identified by the Plaintiff and the proposed common issues...

$E$ : The proposed common issue must be a substantial ingredient of each class member's claim and its resolution must be necessary to the resolution of that claim....

F: A common issue need not dispose of the litigation; it is sufficient if it is an issue of fact or law common to all claims and its resolution will advance the litigation for (or against) the class....

$G$ : With regard to the common issues, "success for one member must mean success for all. All members of the class must benefit from the successful prosecution of the action, although not necessarily to the same extent." That is, the answer to a question raised by a common issue for the plaintiff must be capable of extrapolation, in the same manner, to each member of the class....

$H$ : A common issue cannot be dependent upon individual findings of fact that have to be made with respect to each individual claimant....

I: Where questions relating to causation or damages are proposed as common issues, the plaintiff must demonstrate (with supporting evidence) that there is a workable methodology for determining such issues on a class-wide basis....

$J$ : Common issues should not be framed in overly broad terms. ${ }^{81}$

The upshot of the foregoing analysis is this: in establishing commonality for class certification, every court must tread a fine line between the following considerations:

1. On the one hand, common issues need not be determinative of liability and an issue can be a common issue even if it makes up a very limited aspect of the liability question and even though many individual issues remain to be decided after its resolution.

2. Yet on the other hand, common issues cannot be common in the most general terms.

3. Hence, the "commonality" hurdle of certification is likely to be satisfied if the resolution of common issues moves the litigation forward, even though individual issues may predominate over common issues.

Thus, if we imagine the interrelation between common and individual issues as an ascending scale from 0 percent predominance of common over individual issues (meaning that the resolution of common issues does not advance the lawsuit at all) to 100 percent predominance (meaning that the resolution of common issues fully determines the fate of the 
lawsuit so that no individual fact-finding is even necessary), then the lowest range of the proper commonality standard would be located somewhere in between 0 percent predominance and $50+$ percent predominance.

\section{THORBURN VERSUS GOOD: Two Monologues do Not Make a Dialogue}

The previous section portrayed the relationship between individual and common issues in any putative class action as an ascending scale: ranging from 0 to 100 percent predominance of common over individual issues. In the section that follows, I will argue that not only has the Court in Thorburn failed to properly locate the situation at hand on that scale but, on closer scrutiny, it also misconstrued the scale itself. The Court in Good, on the other hand, got both of the issues right.

\section{A. THORBURN V. BRITISH COLUMBIA (Public Safety and Solicitor General)}

\section{OVERVIEW}

At issue in Thorburn was certification of the proposed class action in respect of routine strip searches carried out at the Vancouver Jail from 2001 to $2006 .{ }^{82}$ In 2001, the Supreme Court of Canada found routine strip searches to be contrary to section 8 of the Charter as inherently humiliating and degrading. ${ }^{83}$ Notwithstanding the judgment in Golden, the practice endured in the Vancouver jail until 2006, at which point it was formally eliminated. ${ }^{84}$ During the outlined period, the policy in regard to strip searches was formulated by the Province and, barring a few exceptions, mandated the "one-size-fit-all" approach which required the police officers to strip search all new arrivals. ${ }^{85}$

The class of aggrieved detainees sought damages pursuant to section 24(1) of the Charter, citing Ward ${ }^{86}$ for the alleged violation of the section 8 Charter rights. ${ }^{87}$ The problem, as the plaintiff's counsel briskly put it, was that the jail authorities "didn't listen to the Supreme

As the Court in Thorburn explained at para 36: "The operation of the Jail was guided by various policies and procedures. Staff conducted searches of new arrivals at the facility in accordance with the 'Vancouver Jail Policy and Procedure Manual' (policy) and to a lesser extent, the Corrections' Adult Custody Manual" (Thorburn BCSC, supra note 8).

83 See $R v$ Golden, 2001 SCC 83 [Golden], as discussed in Thorburn BCCA, supra note 8 at para 9. In Golden, the Supreme Court of Canada held that strip searches incident to arrest required reasonable ground and could not be performed on a routine basis. Writing for the majority, Justice Iacobucci and Justice Charron described strip searches as "inherently humiliating and degrading for detainees regardless of the manner in which they are carried out and for this reason they cannot be carried out simply as a matter of routine policy" (Golden, ibid at para 90).

In April 2006, the VPD assumed control of the Jail. Following the change in the control of the Jail, a new policy (new policy) was put in place regarding prisoner searches. This policy has eliminated the practice of routine strip searches of new arrivals. Whether a strip search is conducted is determined on a case by case basis having regard for specific criteria that take into account a number of factors. 
Court of Canada" back in 2001, which resulted in "an estimated 15,000 strip searches per annum between 2001 and 2006," a number that "represents a significant atrocity." 88

The trial judge dismissed the application for certification and found that the claimants "failed to establish four out of the five s. 4(1) requirements, accepting only that they had satisfied the requirement for an identifiable class." 89 Among the common issues that failed at trial was whether the strip searches performed on class members constituted a violation of their rights protected under section 8 of the Charter. The Court sided with the defendants in that "the plaintiffs' proposed common issues have a fatal flaw: the lack of commonality." 90 A unanimous Court of Appeal agreed. In the remainder of this section, I will explain why the proposition that underpinned the reasoning of the Court — that "the common issues" "lack commonality" - is question-begging on many levels.

There are two ways to to construe the Court's reasoning. One way is to embrace the notion that " $[\mathrm{t}]$ he resolution of these common issues will not avoid individual fact finding and legal analysis to answer the same question for each class member." 91 In particular, the trial judge identified a host of practical difficulties arising out of the plaintiffs' common issues, including the fact that "the legal tests require individual analysis of each potential plaintiff"s case to determine if there was a violation of applicable legal standards" and that "hundreds of employees made individual assessments as to whether a strip search was appropriate in a particular case. ${ }^{.92}$ However, two doctrinal counter-arguments can be made in this respect. First, as we know from the previous section, in order to pass the commonality threshold it is perfectly acceptable for individual issues to predominate over the common issues as long as the resolution of the latter moves the litigation forward. Indeed, as the trial judge emphasized herself, in British Columbia, the Class Proceedings Act expressly precludes the predominance of common issues over individual issues to be considered as a factor in determining the requisite commonality. ${ }^{93}$ Second, as the Ontario Court of Appeal noted in Cloud v. Canada (Attorney General), the drafters of Canadian class proceedings legislation specifically rejected the requirement that the common issues should predominate over the individual issues in order for the class action to be the preferable procedure and an issue can be a common issue even if it makes up a very limited aspect of the liability question and even though many individual issues remain to be decided after its resolution. ${ }^{94}$ Thus, conceptually, the need for "individual analysis of each potential plaintiff's case" and the finding of requisite commonality are not mutually exclusive.

A perhaps more helpful way to look at the British Columbia Supreme Court's utterance is to take the defendant words at their face value and concur that the common issues are so unsubstantial that "their resolution would not move the litigation forward" "in any meaningful way." 95 Another way to put it is that the resolution of the common issues, as the

Gerry Bellett, "Protesters Seek to Launch a Class-Action Lawsuit Over Strip Searches in Vancouver Jail," Vancouver Sun (3 April 2012), online: $<$ www.vancouversun.com/news/Protesters+seek+launch+ class+action+lawsuit+over+strip+searches+Vancouver+jail/6405939/story.html>.

Thorburn BCCA, supra note 8 at para 32.

Thorburn BCSC, supra note 8 at para 94.

Ibid.

Ibid at para 102 .

Ibid at para 100 .

(2004), 73 OR (3d) 401 (CA).

Thorburn BCCA, supra note 8 at paras 40,42 . 
Court put it, would "obscure" resolution of the the individual issues. ${ }^{96}$ This reading, however, is not without difficulties of its own.

The Court of Appeal noted that the claimants "could not rely merely on their claim that the policy for strip searching all new arrivals ... was unreasonable in order to establish a cause of action for the proposed class members." ${ }^{, 97}$ Indeed, as was established by the trial court, the presumption of reasonableness is rebuttable and 'the plaintiffs' case will require the assessment of thousands of strip searches to determine which ones were in violation of legal standards" and which ones were not. ${ }^{98}$ However, on closer scrutiny it becomes doubtful whether the "consideration of the multifarious circumstances of each class member (e.g., the reason for the arrest, any prior criminal record or acts of violence...) ${ }^{999}$ was even warranted as part of the test for certification.

\section{TEST FOR UNLAWFUl SEARCH AND EX ANTE CONSIDERATIONS}

The test for unlawful search is well-established and involves balancing the "competing values of privacy and law enforcement." 100 In Hunter v. Southam Inc., the Supreme Court enunciated the basic framework for analysis that imposes certain procedural elements. ${ }^{101}$ First, the Supreme Court held that prior authorization, where feasible, is a precondition for a valid search and seizure: warrantless search is presumptively unreasonable. ${ }^{102}$ "At the same time, the power to search 'incident to arrest' has developed as a long-standing exception to this customary rule," 103 even though "this common law power has been carefully narrowed and confined by the Supreme Court of Canada," 104 including the restrictions imposed by the judgment in Golden. Of important note is the fact that the justification for a search should be provided before the search has been carried out as doing otherwise would be "inconsistent with the notion of an individual right to hold that, if the police find something, the search was reasonable, for that is to invite searches on a whim."105

In Golden - the case that underpinned the legal framework for the proposed class action in Thorburn - the Supreme Court held that a strip search incidental to arrest required reasonable grounds and could not be "carried out simply as a matter of routine policy."106 Moreover, the Supreme Court held that reasonable grounds for arrest did not confer automatic authority on the police to carry out a strip search incident to arrest and that "additional grounds pertaining to the purpose of the strip search are required"107 (for example, the need to reveal a particular piece of evidence or a weapon). Hence, the Supreme Court held that "a 'routine' strip search carried out in good faith and without violence will

Thorburn BCSC, supra note 8 at para 105.

Thorburn BCCA, supra note 8 at para 41.

Thorburn BCSC, supra note 8 at para 96.

Thorburn BCCA, supra note 8 at para 41.

Hon Robert J Sharpe \& Kent Roach, The Charter of Rights and Freedoms, 5th ed (Toronto: Irwin Law, 2013) at 291.

[1984] 2 SCR 145 [Hunter].

Ibid at 161 .

Golden, supra note 83 at para 23.

Christensen, supra note 17 at 236.

Sharpe \& Roach, supra note 100 at 291-92. See also Golden, supra note 83 at para 89.

Golden, ibid at para 90.

Ibid at para 98. See also Thorburn BCCA, supra note 8 at para 9. 
also violate s. 8 where there is no compelling reason for performing a strip search in the circumstances of the arrest." 108

Thus, one can cast a (pretty heavy) shadow of doubt on Thorburn's assertion that "[ $\mathrm{t}] \mathrm{he}$ policy, whether or not it is flawed, is not at issue; rather, it is the lawfulness of the search that forms the matter of inquiry." 109 Indeed, why can an unreasonable policy not provide a foundation for establishing the requisite commonality? First, as Joseph Arvay and David Wu argue, "to hold that s. 8 cannot be established based on an unreasonable policy alone is counterintuitive to Charter rights in general, which apply to all government acts including their laws and policies." 110 Second, as some commentators remind us, the very same Vancouver jail's policy implicated in Thorburn determined the award of section 24(1) damages to the claimant in Ward. ${ }^{111}$ Third, and most importantly, it was the very existence of the "one-size-fit-all" policy, and not any individual "consideration of the multifarious circumstances of each class member," "112 that prompted each officer to conduct the routine strip search of every single arriving detainee.

To supply a useful analogy, imagine a recipe book that mandates exactly two tablespoons of salt to be added to each dish, no matter the size or nature of what one is cooking. Surely, it would taste terrible in the overwhelming majority of the cases; however, it may well work out in some rare instances and the proud chef may try to take all credit for a well turned out dish. The question is, however, are we going to trust the chef that the wonderful result can be attributed to their meticulous judgment as opposed to unadulterated luck? Most importantly, though, how are they going to prove it after the fact?

Likewise, as the Supreme Court has held again and again, only an ex ante assessment can lend any credibility to the reasonableness of the search, and, as the Supreme Court asserted in Hunter, ex post facto justification would not suffice. ${ }^{113}$ As one of the commentators put it, "[w]hen the legality of an intrusion was uncertain ex ante, the existence of an obviously lawful alternative strongly indicates that the decision to proceed was unreasonable."114 Hence, section 8 requires a strategy for preventing unreasonable searches before they happen, "not merely for identifying and remedying them after the fact."115 The Supreme Court in Hunter has supplied a useful point of reference in this regard:

[A] post facto analysis would ... be seriously at odds with the purpose of s. 8 . That purpose is, as I have said, to protect individuals from unjustified state intrusions upon their privacy. That purpose requires a means of preventing unjustified searches before they happen, not simply of determining, after the fact, whether they ought to have occurred in the first place. This, in my view, can only be accomplished by a system of prior authorization, not one of subsequent validation. ${ }^{116}$

Ward, supra note 31 . See also Christensen, supra note 17 for an argument on this point.

Thorburn BCCA, supra note 8 at para 41.

Hunter, supra note 101.

Steven Penney, "Taking Deterrence Seriously: Excluding Unconstitutionally Obtained Evidence Under Section 24(2) of the Charter" (2004) 49:1 McGill LJ 105 at 140.

Michael Plaxton, “Actions for Trespass \& Hunter v. Southam" (2007) 57 UNBLJ 215 at 220.

Hunter, supra note 101 at 160 [emphasis in original and added]. 


\section{ShIFTING THE ONUS OF PROOF}

Implicit in the foregoing argument is the proposition that, as the Court kept repeating in Thorburn, "a warrantless search is presumptively unreasonable." 117 Practically speaking, this means that, once the Court established the unconstitutionality of the blanket policy that underpinned the strip search practice, the onus shifted to the authorities to justify each particular case of a strip search. Given that the policy was blanket and all-encompassing, one is probably talking a handful of cases (if any at all ${ }^{118}$ where, instead of relying on the blanket policy, the officer decided to conduct the search "based on the kind of careful, individualized assessment required by Golden." "In all likelihood, however, there would be a paucity of evidence to provide this kind of ex ante justification - perhaps several cases at best which is a far cry from the Court's suggestion that 'the plaintiffs' case will require the assessment of thousands of strip searches to determine which ones were in violation of legal standards." ${ }^{120}$ It follows, then, that such exception would not justify the conclusion that the case lacks requisite commonality. As one of the commentators observed:

\footnotetext{
Viewed in this light, it is hard to argue that none of the thirteen common issues proposed by the plaintiffs in Thorburn would avoid duplication of fact-finding or legal analysis, advance the litigation for (or against) the class, or be capable of extrapolation to each member of the class in a manner that would justify certification. Even if a common issues trial were to be held assessing just the three issues enumerated above, there seems to be little doubt that the litigation would be significantly advanced either for or against the class. ${ }^{121}$
}

Thus, it appears that in order to find the requisite commonality, the Thorburn Court was not required "to have a more careful look at the defendant's records to determine whether reasonable and probable ground existed for the search, which may disqualify a potential class member." "122 All they had to do was establish the unreasonableness of policy, which would have shifted the burden of justification to the police. Thus, not only did the Court reason as if predominance was part of the commonality test (which it is not), but the Court failed to see that all it had to establish was unreasonableness of the policy, whereupon the burden of proof would shift to the police.

\section{B. Good V. ToRonto Police SERVICES BoARD}

\section{FALSE DiCHOTOMY}

It may be argued, and justifiably so, that the legacy of Thorburn presents us with a spurious dilemma: either an infringement of a Charter right can be established on the unreasonableness of a general policy alone, ${ }^{123}$ or it "will require the assessment of thousands of strip searches to determine which ones were in violation of legal standards" and which 237.

Ibid.

Thorburn BCSC, supra note 8 at para 96.

Christensen, supra note 17 at 238 [footnotes omitted].

Thorburn BCSC, supra note 8 at para 93.

Thorburn BCCA, supra note 8 at para 41. 
ones were not. ${ }^{124}$ However, as Joseph Arvay and David Wu rightly observe, "these are not mutually exclusive considerations." 125 Indeed, what the Court portrayed in Thorburn as the considerations pulling in opposite directions has been unproblematically reconciled in Good.

\section{OVERVIEW}

At issue in Good was a proposed class action against the Toronto Police Services Board and three other defendants, asserting multiple claims arising out of the G20 Summit held in Toronto in 2010. ${ }^{126}$ Approximately 1,000 individuals were arrested and taken to a central Detention Centre specially constructed for the G20 event, where the conditions were conspicuously poor. ${ }^{127}$ Among the common issues proposed by the claimant was whether "“each mass detention and/or arrest (or the prolonged duration thereof)' constituted false imprisonment and/or arbitrary detention or imprisonment contrary to s. 9 of the Charter." 128

The motion judge held that the latter was not a satisfactory common issue. By making an argument strikingly reminiscent of Thorburn, she rejected the plaintiff's claim that "because a command was made to arrest a group, the lawfulness of that arrest could be decided in common." 129 Instead, she held that since individual officers were responsible for deciding whether detention, arrest, and a charge were appropriate, and since individual conduct among protesters varied, individual fact-finding was in order. This, in her opinion, led to an early demise of the plaintiff's motion for certification.

\section{FINDING OF COMMONALITY}

On appeal, this finding was reversed. The Divisional Court, and then Ontario Court of Appeal, found it difficult to see why section 9 infringement, which would otherwise indeed require individual assessment of each detainee's case (section 9 and section 8 tests are very similar in this respect), ${ }^{130}$ could not be found in the face of a blanket all-encompassing command, which effectively rendered any individual assessment otiose.

As the Divisional Court reasoned, the "central feature of the [section 9] test is the requirement that the officer, who gives the order to detain a person, must have reasonable cause to suspect that the person 'is criminally implicated in the activity under investigation." 131 This test is similar to that discussed in Thorburn. However, the Divisional Court said that individual consideration was not warranted since "the allegation is that the command order was given without regard to whether any particular individual swept up in the mass detention was or was not implicated in the unlawful activity with which the police were concerned." 132 In other words, each proposed subclass shared the commonality of the alleged command order. As the Court of Appeal further observed: "The motion judge's

\footnotetext{
124 Thorburn BCSC, supra note 8 at para 96. Arvay \& Wu, supra note 6 at 15 . Good ONCA, supra note 11 at para 2. Ibid at para 1 .

Ibid at para 19.

Ibid at para 20 [emphasis added].

See Arvay \& Wu, supra note 6 at 16.

Good ONSC, supra note 11 at para 47. Ibid.
} 
conclusion that [the alleged section 9 breach] was not a common issue was rooted in her focus on the possibility of varying individual conduct by the individuals who were arrested or detained which is an error in principle in the context of the class as cast on appeal."133

\section{WHY DIFFERENT?}

One can only speculate as to what prompted drastically different results in such similar cases as Thorburn and Good. Indeed, albeit in both cases proposed common issues implicated some individual issues (because, after all, both section 8 and section 9 of the Charter are indeed "individual in nature"), the Good Court was willing to countenance it, while the Thorburn Court did not. Interestingly, what underpinned the finding of commonality in Good was an alleged command order, while in Thorburn it was the strip search policy, which was neither consistent nor homogenous over the years, ${ }^{134}$ which might have had some bearing on the determination in the case.

All in all, the takeaways from both Thorburn and Good is that, in many important respects, certification is a strong semantic game, so it is vital not to lose sight of the precise parameters of the exact doctrinal tests and not to be deluded by wording (especially the proposition that constitutional rights are "individual in nature"). Unfortunately, the application for leave to appeal from the judgment in Good to the Supreme Court of Canada was refused, ${ }^{135}$ which means that at the present juncture there is no way to know what the apex Canadian court would have to say on the matter. The lower courts continue to treat both Thorburn and Good as valid precedents. ${ }^{136}$

\section{The Form-Substance Dialectics IN CHARTER Class ACTIONS}

\section{A. Procedural or Substantive?}

A useful way to approach the issue of the proper doctrinal framework for the "commonality" threshold of certification is to start with the nature of certification itself. What does it mean to certify an action as a class action? Is this task confined to the mechanical consolidation of individual claims, or is there more to it than a mere procedural shell? Simply put, is the task of aggregating actions into a class action a substantive or procedural task? What about the law that governs this aggregation?

This question is worth pursuing not only because it is normatively plausible that the answer to it would have a substantial bearing on the doctrinal parameters of "commonality", but also because the misconstruction of the real nature of a class action proceeding may lead some authors to believe that, with the advent of the third-party financing, class actions may become redundant and can be substituted by mass actions. ${ }^{137}$ Likewise, the excessive 
emphasis on the mechanical property of class actions to generate monetary recovery obfuscates the hidden power of legal aggregation to address system-wide constitutional violations through injunctive and declaratory relief. However, until now the substantive angle of the class proceeding legislation has not been the focus of explicit theorizing or empirical research.

As Jones observes, whenever the Canadian courts have considered the question, "class action legislation has been regarded as procedural, and not substantive, law."138 The motions judge in Hollick explicitly said that "[ $\mathrm{t}]$ he Class Proceedings Act is essentially a procedural statute. It does not create a new cause of action." 139 In Murphy v. Compagnie Amway Canada, the judge at first instance concluded that class actions are a procedural vehicle whose use neither modifies nor creates substantive rights. ${ }^{140}$ In echoing the foregoing sentiments, the Court in Ontario New Home Warranty Program v. Chevron Chemical Co. remarked:

[t]here is no jurisdiction conferred by the Class Proceedings Act to supplement or derogate from the substantive rights of the parties. It is a procedural statute and, as such, neither its inherent objects nor its explicit provisions can be given effect in a manner which affects the substantive rights of either plaintiffs or defendants. $^{141}$

With respect, this article proposes that such holdings are misguided and that class action legislation is not only procedural, but also substantive in nature. As I will go on to explain, among a plethora of problems that plagued the Court's reasoning in Thorburn was the fact that the Court treated the class action legislation as merely a procedural tool of claim aggregation. Indeed, the appellate Court in Thorburn opened its discussion of the case by calling the Class Proceedings Act "a procedural tool by which a representative individual(s) may, on behalf of similarly-situated individuals, advance multiple claims for an alleged wrong within a single action." "142 However, as will be argued below, "procedure is rarely "solely procedural""143 and, as Jasminka Kalajdzic aptly observes, "it is disingenuous to maintain that there is nothing beyond the procedural in class action litigation"; ${ }^{144}$ indeed, not only is it true that "procedure's very function is to modify the substantive law," " but the class action regime explicitly vests the judges with vast discretion to alter the traditional

138 Jones, supra note 27 at 182.

139 Hollick v Metropolitan Toronto (Municipality of), [1998] OJ No 1288 (QL) at para 20 (Ct J (Gen Div)).

$140 \quad 2015$ FC 958 at para 33. See also McCleod-Kilmurray, supra note 23 at 277.

141 (1999), 46 OR (3d) 130 at para 50 (Sup Ct J) [emphasis added], cited in Jones, supra note 27 at $14, \mathrm{n}$ 24.

Thorburn BCCA, supra note 8 at para 28.

McCleod-Kilmurray, supra note 23 at 277 [footnotes omitted].

Kalajdzic, supra note 48 at 6.

McCleod-Kilmurray, supra note 23 at 277, citing Geoffrey B Hazard, "The Effect of the Class Action Device upon the Substantive Law" (1973) 58 FRD 307 at 307 . In reference to Hazard, McCleodKilmurry states at 277, n 68:

The author paraphrased the Solicitor General of the United States (Maitland) by saying that "the substantive law is laid down in the interstices of procedure.... Substantive law is shaped and articulated by procedural possibilities. Moreover, the function of procedure would be unintelligible if it were not to have substantive consequences. So the question $\ldots$ in the relation of substance and procedure is one of pace and of role: How quickly and how far should the courts go in using procedural devices that are in their disposal? The necessary technique is one of circumspect consideration of the appropriate role of the judicial institution in shaping the substantive consequences of procedures such as those established in Rule 23." 
doctrinal landscape of substantive rights in the pursuit of policy goals advanceable by class actions. This is yet another reason why the individual nature of a putative grievance per se should not be readily dismissed by the court as a hindrance to aggregation.

\section{B. GLOSSING OVER INDIVIDUALIZED INQUIRIES IN AgGREgate Litigation}

\section{Civil Litigation}

In civil litigation, substantive gains that procedural aggregation confers on the plaintiffs are not confined to those derived solely from the "economy of scale." Frequently, such gains stem directly from the court's willingness to exercise its broad discretionary mandate and creatively overcome differences inherent in any semi-heterogeneous collective dispute. The most common way for the court to accommodate such differences is to "gloss over" some individual elements of the claim.

Examples of such accommodation abound. In mass tort litigation, courts routinely sacrifice individual elements of a negligence claim in exchange for gains accruing to a class. For instance, not only does the class litigation regime allow certification based on exposure alone $^{146}$ (thus shying away from the inquiry into each person's injury before deciding whether they are members of the class) ${ }^{147}$ but courts habitually deal with causal mechanisms that cannot be traced but only inferred statistically (for example, when determining whose sickness can be attributable to the defendant). ${ }^{148}$ Likewise, where negligent misrepresentation is alleged, some courts recognize that instead of actual proof of reliance, there may be a "presumption of reasonable reliance," which would make some common law misrepresentation claims appropriate for consolidated treatment. ${ }^{149}$

American jurisprudence is particularly illustrative of a myriad of ways in which courts can bring some procedural changes to bear on the substantive outcomes of a case. For instance, the US courts have long used the class action regime as a "catalyst" for expansive interpretation in securities fraud. ${ }^{150}$ Likewise, many have noted that the courts had relaxed the requirement of "reliance" in securities and product misrepresentation class actions. ${ }^{151}$ Even more broadly, courts are now willing to "gloss over" the requirement of showing individualized proof of negligence in mass torts and have routinely substituted it with strict product liability. ${ }^{152}$

In Canada, as Jones submits, each jurisdiction "permits the calculation of an aggregate award without proof of individual causation in any particular case; and all allow the courts discretion to distribute the money, not only to the class members, but also to any entity or

Bywater v Toronto Transit Commission, [1998] OJ No 4913 (QL) (Ct J (Gen Div)).

Jones, supra note 27 at 229.

Ibid at 229-30.

Michael A Eizenga et al, Class Actions Law and Practice, 2nd ed (Markham: LexisNexis Canada, 2009) (loose-leaf updated 2018), § 3.75.3. See also Ramdath v George Brown College, 2010 ONSC 2019; McKenna v Gammon Gold Inc, 2010 ONSC 4068 at paras 36-37.

Hal Scott, "The Impact of Class Actions on Rule 10b-5" in Robert M Cover \& Owen M Fiss, eds, The Structure of Procedure (Mineola, NY: Foundation Press, 1979) 86.

Garrett, supra note 7 at 600 .

Ibid at 601 . 
fund that the court deems would be for the class members' benefit." ${ }^{\text {"153 }}$ Likewise, Canadian class action legislation provides that the traditional limitations periods may be altered or suspended if the goals of class actions are to be served. ${ }^{154}$ Some commentators even go as far as to suggest that class action legislation per se is capable of creating a new cause of action: "Despite its ostensibly procedural nature, there may be persuasive arguments that the Ontario class proceedings legislation creates a new cause of action - a mass tort remedy where previously one did not exist or existed only tenuously." "155 As some authors note in this regard:

The very fact of legislating the procedure of class actions suggests widespread support for the kinds of substantive issues raised by class proceedings, as they permit some issues to be raised, and raised more powerfully, than they could have been without this procedural option. Certain substantive rights can be exercised which may have been lost. ${ }^{156}$

From this, one can surmise that there are two levels on which procedural aggregation may affect the substantive content of the class proceeding. First, the form in which an inquiry is cast may naturally affect the substance of the inquiry itself. ${ }^{157}$ Second, the statutory scheme drafted by the legislator explicitly vests the court with the discretionary mandate to alter some procedural aspect of the proceeding in the furtherance of substantive purposes of the class action regime. ${ }^{158}$

\section{CHARTER ClASS ACTIONS}

As is evident from the foregoing analysis, courts are routinely willing to sacrifice individual elements of a putative claim in the name of a more noble goal-for instance, making sure that justice is served for a large number of otherwise disenfranchised individuals. Implicit in this finding is the fact that the form of dispute resolution (individual or aggregate) may be brought to bear on the substantive outcomes of Charter litigation.

Jones, supra note 27 at 5 .

Ibid at 183 .

Martin Boodman, “The Malaise of Mass Torts" (1994) 20:1 Queen's LJ 213 at 244. The author argues at 241 that Sutherland v Canadian Red Cross Society (1994), 17 OR (3d) 645 at 651 (Ct J (Gen Div)) also represents "judicial recognition that mass torts are clearly within the contemplation of the statute."

156 McCleod-Kilmurray, supra note 23 at 278.

157 See e.g. Duncan Kennedy, "Form and Substance in Private Law Adjudication”(1976) 89:8 Harv L Rev 1685.

158 See e.g. Bank of Montreal v Marcotte, 2014 SCC 55 at para 31, wherein the Supreme Court concluded that the statutory rules of civil procedure must be interpreted in harmony with the provisions governing class actions "in order to achieve the outcome that is best suited to the goals of class actions." Thus, after inquiring into whether the law permits a collective action where the representative does not have a direct cause of action against, or a legal relationship with, each defendant, the Supreme Court responded in the affirmative (ibid). See also the dissenting opinion of Justice Karakatsanis and Justice Cromwell in SunRype Products Ltd v Archer Daniels Midland Company, 2013 SCC 58, wherein Justice Karakatsanis remarked on the inherently substantive nature of the class action regime: "while class actions are a procedural vehicle, they are not merely procedural. They make possible claims that are very complex or could not be prosecuted individually, not only because it would be inefficient or unaffordable, but also because it may be extremely difficult to prove individual claims" (ibid at para 107) [emphasis in original]. Cf Justice Rothstein's position in this case who, writing for the majority, suggested that Justice Karakatsanis' approach creates a new cause of action (ibid at para 75) and, as such, "subverts the purpose of class proceedings" (ibid at para 67) - a conclusion with which this article respectfully disagrees. 
For one thing, there is nothing in the extant jurisprudence that would prevent the court from creatively approaching the issues of individualized proof and individualized causation as part of the commonality hurdle of certification in Charter class actions. Not only are the courts deliberately vested with wide statutory discretion to advance the public interest in securing the class action as a vital aspect of the public justice system, but in the realm of constitutional adjudication - of all the fields - such public interest appears to be the most pressing. This is particularly so because those entitled to Charter protection are by default a disenfranchised minority who cannot press for systemic changes through traditional democratic channels of reform. Thus, as one commentator observed:

Even when a proposed class action is not certifable in the form presented to the court, if the objectives of judicial economy, access to justice, and behavior modification so demand, under section 7 of the CPA the court has discretion to add or delete parties, order the amendment of the pleadings, or "make any further order it considers appropriate" to enable the proceeding to be certified. ${ }^{159}$

Furthermore, in the constitutional realm, the true appreciation of the substantive nature of procedural aggregation is especially important because the amplified opportunity to pursue impact litigation may help "to press forward new constitutional theories." 160 Conversely, failure to appreciate the substantive goals behind the class action regime may lead to the dilution of the substantive guarantees afforded to the citizens by the Charter. Some American commentators argue that it was precisely the American courts' inability to grasp the substantive policy goals behind the class action regime that let the courts to over time render some constitutional rights unsuitable to class action resolution. ${ }^{161}$

Thus, while taking procedure out of its substantive context is pernicious enough when it happens in the civil litigation context, the ramifications of such doctrinal myopia in the context of public litigation can be even more far-reaching. Given that the ultimate goal of the class action regime is behaviour modification, the courts should be willing to creatively navigate the procedural landscape of claim aggregation in order to deter system-wide constitutional violations. Some commentators already draw attention to the fact that the correct Charter class action regime does not see the forest for the trees, that is, does not give due consideration to the ultimate objectives of aggregation. In the context of the Thorburn decision itself, the worries are presented as follows:

Rather than refusing to take issue with a strip-search policy that required the officers at the Vancouver jail to routinely violate section 8 of the Charter, in the interests of access to justice, judicial economy, and the modification of behavior that is "inherently humiliating and degrading," the BC Supreme Court and BC Court of Appeal ought to have at least more carefully considered ways in which a class action could have been used to address the serious claims advanced in Thorburn. 
This author sincerely hopes that the Court of Appeal for Ontario and the Supreme Court of Canada will take the opportunity presented by Good to yet again reinforce the ambitious goals of Canada's class proceedings legislation and endorse class actions as a realistic means of furthering police accountability and defending the sanctity of Canadians' Charter rights. ${ }^{162}$

Reminiscent of this perspective is Chief Justice McLachlin's pronouncement in Hollick that "it is essential ... that courts not take an overly restrictive approach to the legislation, but rather interpret the Act in a way that gives full effect to the benefits foreseen by the drafters." $" 163$

Taking this background into account, this article argues that, in the context of Charter class actions, the role of procedural consolidation in general - and the "commonality" hurdle of certification in particular - should be reconsidered from the group up, having regards to both traditional policy goals of claim aggregation (access to justice, judicial economy, and behaviour modification) as well as idiosyncratic needs and characteristics of public litigation, including its implications for the theory of democratic governance, collective justice, and constitutional interpretation more broadly.

\section{CONCLUSION}

Even a cursory look at the literature reveals scant agreement among experts on the future of Charter class actions. In no small part, this uncertainty can be attributed to the divergent views among the courts concerning the proper contours of the commonality threshold for aggregate Charter proceedings. While the doctrinal narrative of Thorburn suggests that Charter rights are individual in nature and, thus, are not easily amenable to collective redress, ${ }^{164}$ the counter-narrative delivered by Good posits that in order for a Charter class action to pass the commonality hurdle of certification "it does not have to resolve all issues that may exist in terms of establishing liability." 165 Although it is easy to see Thorburn and Good as thesis and antithesis, the subsequent Charter class actions such as Murray can hardly be portrayed as a synthesis. Hence, uncertainty over the commonality standard reigns.

In responding to the foregoing uncertainty, this article makes a case for revisiting the commonality requirement in Charter class actions and argues that the "overindividualization" of Charter rights that has been imputed into the commonality analysis by Thorburn is unjustified on both descriptive and normative levels. Descriptively, not only did the Thorburn Court fail to acknowledge that the class proceedings legislation allows individual issues to predominate over common issues in the course of certification analysis, but a prudent analysis of Thorburn would reveal barely any need for individual fact-finding at all. Given that a determination of the impugned policy's unreasonableness would shift the onus of proof to the defendant and, consequently, would require that the latter furnishes evidence to corroborate an ex ante reasonableness of each putative strip search (which, as evinced earlier in this article, the defendant would unlikely be able to do), this would either 
make individual fact-finding obsolete or leave it to be litigated later in separate mini-trials, if necessary.

Normatively, the basic presupposition that underpins Thorburn - that the individual nature of a particular wrong per se may serve as a bar to certification - sends the wrong message to both courts and potential claimants by trivializing the extent to which the class action regime is animated by the ambition to overcome the hindrances presented by the individual issues inherent in any collective dispute and, thus, is capable of affecting substantive, not just procedural, rights of the parties. Indeed, class action legislation, albeit dressed in procedural garb, is in fact an idiosyncratic type of a normative regime that mediates between procedural and substantive elements and, in doing so, can profoundly affect the contours of the substantive rights and duties vested in each party to the dispute. Such changes, among other things, can manifest themselves in substituting individual with aggregate inquiries in the furtherance of certain policy objectives. This is particularly so given that there is a clear guidance offered by the Supreme Court in Hollick that class proceeding statutes "should be construed generously" "with a view to their underlying policy goals, which include enhancing access to justice to the country's most marginalized.

The latter goal should not be taken by the courts lightly. It is worth remembering that the very rationale behind the entrenchment of Charter rights was to provide representation to minorities left out by the majoritarian political process. It means that if the legal system continues to discourage aggregation of Charter grievances as part of judicial redress of systemic constitutional wrongs, more often than not the aggrieved individuals would be left with no avenues of recourse at all. Furthermore, as the American experience with cases like Wal-Mart illustrates, the gravitational pull of overly restrictive approaches to certification may stultify the development of impact litigation for years to come.

Thus, as this article suggests, the way our legal system can best respond to the ThorburnGood dilemma is by interrogating its own procedural parameters and shaping the doctrine of commonality that would be informed by the proper understanding of the policy goals that the class action regime is intended to serve. For if left unresolved, not only would the current uncertainty continue to weaken the ability of Charter plaintiffs to pursue traditional class action claims, but it would also dissuade potential claimants from the innovative use of consolidated litigation outside of the well-trodden ground of the criminal justice system - for instance, in the realm of systemic discrimination. In an effort to forestall such a jurisprudential impasse, this article offers a conceptual skeleton for the prospective discussion and suggests the agenda for future research. 
[this page is intentionally blank] 